\title{
Antifungal activities of basil (Ocimum basilicum L.) extract on Fusarium species
}

\author{
Sunčica Kocić-Tanackov*, Gordana Dimić ${ }^{1}$, Jelena Lević ${ }^{2}$ Ilija Tanackov ${ }^{3}$ and Danijela Tuco ${ }^{4}$ \\ ${ }^{1}$ Faculty of Technology, University of Novi Sad, Bulevar Cara Lazara 1, 21000 Novi Sad, Serbia. \\ ${ }^{2}$ Maize Research Institute, Zemun Polje, Slobodana Bajića 1, 11185 Belgrade, Serbia. \\ ${ }^{3}$ Faculty of Technical Sciences, University of Novi Sad, Trg Dositeja Obradovića 6, 21000 Novi Sad, Serbia. \\ ${ }^{4}$ ETOL JVE d.o.o., Bulevar Vojvode Stepe 40, 21000 Novi Sad, Serbia.
}

Accepted 21 July, 2011

\begin{abstract}
The basil extract composition was determined by the GC-MS method and 38 different components were identified. The major components of the basil extract were estragol $(86.72 \%)$, trans- $\alpha$-bergamotene (2.91\%), eucalyptol (2.67\%), trans-ocimene (1.04\%), linalool $(0.72 \%)$, methyl-eugenol $(0.71 \%)$, etc. The antifungal potential of the basil extract was tested against Fusarium oxysporum, $F$. proliferatum, $F$. subglutinans, and $F$. verticillioides isolated from cakes, using the agar plate method. Extract concentrations of 0.35 and $0.70 \%(\mathrm{v} / \mathrm{v})$ significantly inhibited the growth of $F$. proliferatum $(33.37$ and $44.30 \%$, respectively) and $F$. subglutinans (24.74 and $29.27 \%$, respectively) whereas other investigated Fusarium species exhibited much lower sensitivity. The basil extract completely inhibited the growth of investigated Fusarium spp. at the concentration of $1.50 \%(v / v)$. Higher concentrations $(0.35$ and $0.70 \%$ $(v / v))$ reduced growth of aerial mycelium in all tested species. Strong medium pigmentation in the case of $F$. proliferatum and $F$. verticillioides was observed. The microscopic examination of the samples confirmed the presence of hyphae deformations with a frequent occurrence of fragmentations, thickenings and diminished sporulation. In addition to the basic, sensory, role the extract of basil has in the food product, it exerted significant antifungal properties, depending on its concentration.
\end{abstract}

Key words: Basil (Ocimum basilicum L.) extract, components, antifungal activity, Fusarium spp.

\section{INTRODUCTION}

Fusarium species are frequent contaminants of cereals (corn, barley, wheat, oats, rye, rice, etc.), cereal products (flour, bread, cakes, etc.), fruits and vegetables (Pitt and Hocking, 1997; Lević et al., 2004). Enormous economic damages take place as a consequence of food deterioration caused by metabolic activity of microorganisms. In addition, Fusarium species possessing the genetic base for mycotoxin production can biosynthesize zearalenons, trichothecenes (T-2 toxins, HT-2 toxin, deoxynivalenol, nivalenol, etc.), fumonisins, monilioformin, fusarin C, etc. (Thrane, 2001). The consumption of food contaminated with mycotoxins has been associated with various diseases in humans, livestock, and domestic animals. They have been recognized as causes of cytotoxicity, hepatotoxicity, teratogenicity, mutage-

\footnotetext{
*Corresponding author. E-mail: suncicat@uns.ac.rs.
}

nicity, neurotoxicity, etc. (Joffe, 1974; Marasas et al., 1984).

In practice, the use of synthetic preservatives has been the main choice in attempts to prevent microbial spoilage of food commodities and, consequently, the biosynthesis of toxic metabolites. However, today, consumers demand a less use of synthetic preservatives and additives but still expect natural and, above all, safe food. Hence, comprehensive studies have been carried out recently on the use of essential oils, extracts and oleoresins extracted from spices and other aromatic herbs as alternative preservatives providing longer shelf-life and minimal changes in food quality (Benkeblia, 2004; Burt, 2004; Bakkali et al., 2008; Viuda-Martos et al., 2007, 2008; Fawzi et al., 2009; Tajkarimi et al., 2010). The main advantage of extracts is the absence of microbial contamination unlike natural spices which are frequently heavily loaded with microorganisms (McKee, 1995; Karan et al., 2005; Kocić-Tanackov et al., 2009). The antimicrobial 
activity of extracts has been attributed to many active phytochemicals, inclunding flavonoides, terpenoides, carotenoides, coumarins, and curcumines (Burt, 2004; Ceylan and Fung, 2004; Tepe et al., 2005; Viuda-Martos et al., 2007).

Basil is a popular culinary herb, and its essential oils have been used extensively for many years in the flavoring of confectionary and baked goods, condiments (example, ketchups, tomato pastes, chili sauces, pickles, and vinegars), sausages and meats, salad dressings, nonalcoholic beverages, ice cream, and ices (Suppakul et al., 2003).

The objective of this study was to evaluate the antifungal potential of the commercial basil (Ocimum basilicum L.) extract, intended for uses in food, against some Fusarium spp. isolated from cakes.

\section{MATERIALS AND METHODS}

\section{Basil extract}

For the antifungal activity testing, a commercially available, food grade basil extract was provided from ETOL Tovarna arom in eteričnih olj d.d., Celje, Slovenia.

\section{Determination of basil extract composition}

The composition of extracts was determined by Gas Chromatography - Mass Spectrometry (GC-MS) analyses. The GC-MS analysis was carried out on a Varian T2100 GC-MS instrument equipped with data processor. A fused silica capillary column VF5MS (30 m x $0.25 \mathrm{~mm}$ i.d., $0.25 \mu \mathrm{m}$ film thickness, Varian) was used for the separation of the sample components. The carrier gas ultra pure helium was passed through moisture and oxygen traps with constant flow rate of $0.62 \mathrm{~cm}^{3} \mathrm{~min}$. The following temperature program was used: injector temperature $230^{\circ} \mathrm{C}$, initial temperature $40^{\circ} \mathrm{C}$ (held $5 \mathrm{~min}$ ), temperature increase $5^{\circ} \mathrm{C} / \mathrm{min}$ to $200^{\circ} \mathrm{C}$ and held at this temperature for $25 \mathrm{~min}$. The mass spectrometer was operated in the electron ionization mode. The data acquisition was carried out in the scan mode (range 50 to $550 \mathrm{~m} / \mathrm{z}$ ). The injection volume was $1 \mu \mathrm{l}$. The compounds were identified by matching the mass spectra with NIST Mass Spectra Library stored in the GC-MS database.

\section{Fungal strains}

As test microorganisms, the following fungal strains from the genus Fusarium were used: F. oxysporum Schlecht., F. proliferatum (Matsushima) Nirenberg, F. subglutinans (Wollenw. \& Reinking) Nelson, Toussoun and Marasas and $F$. verticillioides (Sacc.) Nirenberg (syn. F. moniliforme Sheld.). The fungal cultures were isolated from cakes and maintained on Potato Dextrose Agar (PDA) (Merck, Darmstadt) at $4^{\circ} \mathrm{C}$ as a part of the collection of the Laboratory for Food Microbiology at the Faculty of Technology, University of Novi Sad, Serbia.

\section{Determination of the basil extract effect on the Fusarium spp. growth}

The agar plate method was applied in the testing of the antifungal activity of basil extracts. The basic medium for the antifungal tests was PDA. The medium was divided into equal volumes $(150 \mathrm{~mL})$, poured into Erlenmeyer (volume $250 \mathrm{~mL}$ ) flasks and autoclaved at $121^{\circ} \mathrm{C}$ for $15 \mathrm{~min}$ after which it was cooled to $45^{\circ} \mathrm{C}$. The extracts were added to the PDA to achieve the following concentrations: 0 , $0.16,0.35,0.70$, and $1.50 \%(\mathrm{v} / \mathrm{v})$. PDA containing different concentration of basil extract was poured in sterile Petri dishes $(\varnothing 9 \mathrm{~cm})$, $12 \mathrm{~mL}$ into each dish.

Seven-day fungal cultures grown on PDA were used to prepare fungal spore suspension tests. Suspensions of fungi were prepared in a medium which contained $0.5 \%$ Tween 80 and $0.2 \%$ agar dissolved in distilled water and were adjusted to provide initial spore count of $10^{6}$ spores $\mathrm{mL}$ by using a haemocytometer. For each extract dose and fungal species, including the controls, dishes were centrally inoculated by spreading $1 \mu \mathrm{L}$ of a spore suspension $\left(10^{3}\right.$ spores/ $\mathrm{mL}$ ) using an inoculation needle. After inoculation, the Petri dishes were closed with a parafilm.

The effect of the basil extract on fungal growth was evaluated by a daily measurement of the diameter of the radial colony growth during 14 days of incubation at $25 \pm 2^{\circ} \mathrm{C}$. The parafilms were removed from the Petri dishes in which no colony growth was observed after 14 days, and the dishes were further incubated for 16 days ( 30 days in total) at $25 \pm 2^{\circ} \mathrm{C}$. In Petri dishes in which fungal growth was observed from $15^{\text {th }}$ to $30^{\text {th }}$ day, concentration of basil extract used was considered to be minimal inhibitory concentration (MIC). If there was no visible fungal growth after 30 days, fungal spores were transferred using a wet cotton baton to the PDA in which no basil extract was added and were incubated for 5 days at $25 \pm 2^{\circ} \mathrm{C}$ for the determination of fungicide effect (MFC).

The inhibitory effect of the basil extract on fungal growth after 14 days was calculated following the formula:

$I(\%)=(\mathrm{C}-\mathrm{T}) / \mathrm{C} \cdot 100$

Where, I is the inhibition (\%); $\mathrm{C}$ is the colony diameter on the control dish $(\mathrm{cm})$ and $\mathrm{T}$ is the colony diameter on the test dish $(\mathrm{cm})$ (Pandey et al., 1982).

Changes in macroscopic and microscopic features of fungi were also observed and compared to the controls. The macroscopic features of spores were observed using a binocular, magnifying glass Technival 2, Carl Zeiss and the microscopic features using a microscope Aristoplan, Leitz.

\section{Statistical analysis}

Each antifungal test was carried out in 3 series and 2 replications. MS Excel was used to calculate means and standard deviations. Significant differences between values were determined by Duncan's multiple range test $(p<0.05)$, following one-way ANOVA.

\section{RESULTS AND DISCUSSION}

\section{Basil extract composition}

The chemical composition of the basil extract is given in Table 1. A total of 38 components were identified and the major components were estragol (methyl chavicol) $(86.72 \%)$, trans-alfa-bergamotene $(2.91 \%)$, eucalyptol $(2.67 \%)$, trans-ocimene $(1.04 \%)$, linalol - syn. linalool $(0.72 \%)$, methyl-eugenol $(0.71 \%)$, etc. (Table 1$)$. The results suggest that the tested basil extract can be defined as an estragol chemotype. Hasegawa et al. (1997) established the variation in the content of extract constituents depending on the basil $(O$. basilicum) genotype: linalol 
Table 1. Chemical composition of basil extract.

\begin{tabular}{lc}
\hline Compound & Percentage $^{\mathrm{a}}$ \\
\hline$\alpha$-pinene & 0.16 \\
Camphene & 0.05 \\
Sabinene & 0.13 \\
$\beta$-pinene & 0.23 \\
Myrcene & 0.15 \\
$p$-cymene & 0.05 \\
Limonene & 0.22 \\
Eucalyptol & 2.67 \\
cis-ocimene & 0.05 \\
trans-ocimene & 1.04 \\
$\gamma$-terpinene & 0.02 \\
Terpinolene & 0.02 \\
Fenchone & 0.12 \\
Linalol & 0.72 \\
Fenchone & 0.13 \\
Camphor & 0.42 \\
Menthone & 0.10 \\
Borneol & 0.10 \\
Menthol & 0.27 \\
Estragol & 86.72 \\
Carvone & 0.07 \\
Bornyl acetate & 0.21 \\
$\beta$-elemene & 0.37 \\
Methyl eugenol & 0.71 \\
cis- $\alpha$-bergamotene & 0.06 \\
$\beta$-caryophyllene & 0.15 \\
trans- $\alpha$-bergamotene & $\alpha$-guaiene \\
Aromadendrene & 2.91 \\
$\alpha$-humulene & 0.01 \\
$\delta$-guurolene & 0.03 \\
$\beta$-Sainene & 0.04 \\
Cubenol & 0.12 \\
Cadinol & 0.07 \\
Other compounds & 0.29 \\
Sum & 0.49 \\
\hline
\end{tabular}

${ }^{\mathrm{a}}$ Relative area percentage.

(0.14-49.48\%), estragol (0.04-82.79\%), methyl cinnamate (0.00-73.65\%), methyl eugenol (0.02-0.39\%), and eugenol (0.06-16.19\%). On the basis of these findings, the authors defined five chemotypes of $O$. basilicum. The majority of authors address linalol, estragol, eugenol and methyl cinnamate as the major antimicrobial components of basil extracts (Kurita et al., 1981; Reuveni et al., 1984; Meena and Sethi, 1994; Lis-Balchin et al., 1998; Baratta et al., 1998; Dorman and Deans, 2000; Suppakul et al., 2003; Sartoratotto et al., 2004; Sokovic and Van Griensven, 2006; Hussain et al., 2008; Dambolena et al., 2010). However, its composition is largely dependent on the genus, species, geographic and climatic conditions of the cultivation area (Fung and Zheng, 2007).

\section{Effect of the basil extract on the Fusarium spp. growth}

The basil extract at the investigated concentrations exhibited the capacity to reduce or inhibit the growth of the Fusarium species. Tables 2 to 5 give the growth of the fungi $F$. verticillioides, $F$. oxysporum, $F$. proliferatum, and $F$. subglutinans, during the 14 days of the incubation. Table 6 shows the inhibitory effect (\%) of the basil extracts on the colony growth of Fusarium species on the $14^{\text {th }}$ day of incubation.

The growth of the investigated Fusarium spp. was observed already during the first day when the lowest concentration of the basil extract was applied $(0.16 \%$ $(\mathrm{v} / \mathrm{v}))$. At this concentration, a statistically significant reduction in the colony growth compared to the control was determined on the $5^{\text {th }}$ day of incubation of $F$. verticillioides (Table 2), on the $1^{\text {st }}$ day of incubation of $F$. oxysporum (Table 3 ), on the $7^{\text {th }}$ day of incubation of $F$. sublutinans (Table 4), and on the $3^{\text {rd }}$ day of incubation of $F$. proliferatum (Table 5). Higher extract concentrations caused the growth delay of investigated Fusarium spp. with different inhibitory effects on the reduction of the growth rate.

The basil extract concentration of $0.35 \%(\mathrm{v} / \mathrm{v})$ delayed the growth for a day only in $F$. proliferatum, while the growth of the other investigated Fusarium spp. occurred already on the first day of the incubation. At this concentration, statistically significant reduction in the colony growth compared to the control sample was determined in $F$. verticillioides on the $4^{\text {th }}$ day of incubation (Table 2), and for $F$. oxysporum, $F$. subglutinans, and $F$. proliferatum on the $1^{\text {st }}$ day (Tables 3 to 5). At the extract concentration of $0.70 \%(\mathrm{v} / \mathrm{v})$, the growth of $F$. oxysporum, $F$. subglutinans, and $F$. proliferatum was observed on the $2^{\text {nd }}, 3^{\text {rd }}$ and $4^{\text {th }}$ day, respectively. The growth inhibition of all investigated Fusarium spp. at this concentration was statistically significant compared to the control sample.

The growth inhibition of Fusarium spp. after the $14^{\text {th }}$ day of incubation at the lowest concentration was insignificant, ranging from $8.08 \%$ ( $F$. subglutinans) to $15.22 \%$ ( $F$. proliferatum) (Table 6). Concentrations of 0.35 and $0.70 \%(\mathrm{v} / \mathrm{v})$ significantly inhibited the growth of $F$. proliferatum (33.37 and $44.30 \%$, respectively) and $F$. subglutinans (24.74 and $29.27 \%$, respectively), while other investigated Fusarium spp. showed lower sensitivity. At these concentrations, the highest tolerance that is sensitivity was detected in $F$. veriticillioides, $F$. proliferatum, respectively. The complete inhibition of observed Fusarium species was obtained at the 
Table 2. Effect of the basil extract on the colony growth of $F$. verticilioides.

\begin{tabular}{cccccc}
\hline & \multicolumn{5}{c}{ Colony growth diameter (mean and SD=6) (cm) } \\
\cline { 2 - 5 } Day & \multirow{2}{*}{ Control } & $\mathbf{0 . 1 6}$ & $\mathbf{0 . 3 5}$ & $\mathbf{0 . 7 0}$ & $\mathbf{1 . 5 0}$ \\
\cline { 2 - 5 } & & $0.38 \pm 0.029^{\mathrm{abcA}}$ & $0.38 \pm 0.025^{\mathrm{abcA}}$ & $0.29 \pm 0.038^{\mathrm{dA}}$ & $0.00 \pm 0.000^{\mathrm{deA}-\mathrm{N}}$ \\
\hline 1 & $0.42 \pm 0.029^{\mathrm{abcA}}$ & $1.88 \pm 0.014^{\mathrm{abcB}}$ & $1.86 \pm 0.014^{\mathrm{bcB}}$ & $0.98 \pm 0.029^{\mathrm{dB}}$ & $0.00 \pm 0.000^{\mathrm{eA}-\mathrm{N}}$ \\
2 & $1.91 \pm 0.014^{\mathrm{abB}}$ & $2.72 \pm 0.029^{\mathrm{abcC}}$ & $2.52 \pm 0.029^{\mathrm{abcC}}$ & $1.78 \pm 0.076^{\mathrm{dC}}$ & $0.00 \pm 0.000^{\mathrm{eA}-\mathrm{N}}$ \\
3 & $2.78 \pm 0.029^{\mathrm{abcC}}$ & $3.33 \pm 0.025^{\mathrm{abD}}$ & $3.14 \pm 0.014^{\mathrm{cD}}$ & $2.44 \pm 0.052^{\mathrm{dD}}$ & $0.00 \pm 0.000^{\mathrm{eA}-\mathrm{N}}$ \\
4 & $3.38 \pm 0.025^{\mathrm{abD}}$ & $3.76 \pm 0.038^{\mathrm{bE}}$ & $3.58 \pm 0.043^{\mathrm{cE}}$ & $3.03 \pm 0.025^{\mathrm{dE}}$ & $0.00 \pm 0.000^{\mathrm{eA}-\mathrm{N}}$ \\
5 & $3.81 \pm 0.014^{\mathrm{aE}}$ & $4.43 \pm 0.025^{\mathrm{bF}}$ & $4.16 \pm 0.052^{\mathrm{cF}}$ & $3.52 \pm 0.029^{\mathrm{dF}}$ & $0.00 \pm 0.000^{\mathrm{eA}-\mathrm{N}}$ \\
6 & $4.56 \pm 0.014^{\mathrm{aF}}$ & $4.98 \pm 0.029^{\mathrm{bG}}$ & $4.53 \pm 0.076^{\mathrm{cG}}$ & $4.23 \pm 0.058^{\mathrm{dG}}$ & $0.00 \pm 0.000^{\mathrm{eA}-\mathrm{N}}$ \\
7 & $5.11 \pm 0.088^{\mathrm{aG}}$ & $5.45 \pm 0.050^{\mathrm{bH}}$ & $5.18 \pm 0.025^{\mathrm{cH}}$ & $4.66 \pm 0.052^{\mathrm{dH}}$ & $0.00 \pm 0.000^{\mathrm{eA}-\mathrm{N}}$ \\
8 & $5.65 \pm 0.050^{\mathrm{aH}}$ & $5.89 \pm 0.038^{\mathrm{bl}}$ & $5.43 \pm 0.029^{\mathrm{cl}}$ & $5.11 \pm 0.088^{\mathrm{dl}}$ & $0.00 \pm 0.000^{\mathrm{eA}-\mathrm{N}}$ \\
9 & $6.07 \pm 0.058^{\mathrm{al}}$ & $6.25 \pm 0.050^{\mathrm{bJ}}$ & $5.72 \pm 0.058^{\mathrm{cJ}}$ & $5.54 \pm 0.052^{\mathrm{dJ}}$ & $0.00 \pm 0.000^{\mathrm{eA}-\mathrm{N}}$ \\
10 & $6.48 \pm 0.025^{\mathrm{aJ}}$ & $6.48 \pm 0.029^{\mathrm{bK}}$ & $6.03 \pm 0.058^{\mathrm{cK}}$ & $5.73 \pm 0.058^{\mathrm{dK}}$ & $0.00 \pm 0.000^{\mathrm{eA}-\mathrm{N}}$ \\
11 & $6.84 \pm 0.052^{\mathrm{aK}}$ & $6.72 \pm 0.029^{\mathrm{bL}}$ & $6.30 \pm 0.050^{\mathrm{cL}}$ & $6.03 \pm 0.025^{\mathrm{dL}}$ & $0.00 \pm 0.000^{\mathrm{eA}-\mathrm{N}}$ \\
12 & $7.30 \pm 0.050^{\mathrm{aL}}$ & $6.94 \pm 0.072^{\mathrm{bM}}$ & $6.51 \pm 0.088^{\mathrm{cM}}$ & $6.30 \pm 0.050^{\mathrm{dM}}$ & $0.00 \pm 0.000^{\mathrm{eA}-\mathrm{N}}$ \\
13 & $7.58 \pm 0.029^{\mathrm{aM}}$ & $7.18 \pm 0.066^{\mathrm{bN}}$ & $6.83 \pm 0.076^{\mathrm{cN}}$ & $6.56 \pm 0.063^{\mathrm{dN}}$ & $0.00 \pm 0.000^{\mathrm{eA}-\mathrm{N}}$ \\
\hline
\end{tabular}

Values followed by the same small letter (a-e) within the same row are not the significantly different $(p>0.05)$ according to Duncan's multiple range test. Values followed by the same capital letter $(A-N)$ within the same column are not the significantly different $(p>0.05)$ according to Duncan's multiple range test.

Table 3. Effect of the basil extract on the colony growth of $F$. oxysporum.

\begin{tabular}{|c|c|c|c|c|c|}
\hline \multirow{3}{*}{ Day } & \multicolumn{5}{|c|}{ Colony growth diameter (mean and $\mathrm{SD}=6)(\mathrm{cm})$} \\
\hline & \multirow{2}{*}{ Control } & \multicolumn{4}{|c|}{ Basil extract concentration $(\%(v / v))$} \\
\hline & & 0.16 & 0.35 & 0.70 & 1.50 \\
\hline 1 & $0.55 \pm 0.050^{\mathrm{aA}}$ & $0.43 \pm 0.025^{\mathrm{bA}}$ & $0.22 \pm 0.029^{\mathrm{cA}}$ & $0.00 \pm 0.000^{\mathrm{deA}}$ & $0.00 \pm 0.000^{\text {deA- }}$ \\
\hline 2 & $1.73 \pm 0.029^{\mathrm{aB}}$ & $1.64 \pm 0.038^{\mathrm{bB}}$ & $0.84 \pm 0.052^{\mathrm{cB}}$ & $0.38 \pm 0.029^{\mathrm{dB}}$ & $0.00 \pm 0.000^{\mathrm{eA}-\mathrm{N}}$ \\
\hline 3 & $2.26 \pm 0.052^{\mathrm{aC}}$ & $2.14 \pm 0.052^{\mathrm{bC}}$ & $1.65 \pm 0.050^{\mathrm{cC}}$ & $1.33 \pm 0.029^{\mathrm{dC}}$ & $0.00 \pm 0.000^{\mathrm{eA}-\mathrm{N}}$ \\
\hline 4 & $2.69 \pm 0.063^{\mathrm{aD}}$ & $2.52 \pm 0.029^{\mathrm{bD}}$ & $2.43 \pm 0.058^{\mathrm{CD}}$ & $2.05 \pm 0.050^{\mathrm{dD}}$ & $0.00 \pm 0.000^{\mathrm{eA}-\mathrm{N}}$ \\
\hline 5 & $2.88 \pm 0.029^{\mathrm{aE}}$ & $2.70 \pm 0.000^{\mathrm{bE}}$ & $2.63 \pm 0.025^{\mathrm{cE}}$ & $2.23 \pm 0.076^{\mathrm{dE}}$ & $0.00 \pm 0.000^{\mathrm{eA}-\mathrm{N}}$ \\
\hline 6 & $3.19 \pm 0.063^{\mathrm{aF}}$ & $3.08 \pm 0.029^{\mathrm{bF}}$ & $2.83 \pm 0.029^{\mathrm{cF}}$ & $2.59 \pm 0.038^{\mathrm{dF}}$ & $0.00 \pm 0.000^{\mathrm{eA}-\mathrm{N}}$ \\
\hline 7 & $3.73 \pm 0.029^{\mathrm{aG}}$ & $3.50 \pm 0.050^{\mathrm{bG}}$ & $3.17 \pm 0.029^{\mathrm{CG}}$ & $2.91 \pm 0.038^{\mathrm{dG}}$ & $0.00 \pm 0.000^{\mathrm{eA}-\mathrm{N}}$ \\
\hline 8 & $4.19 \pm 0.080^{\mathrm{aH}}$ & $3.84 \pm 0.052^{\mathrm{bH}}$ & $3.58 \pm 0.043^{\mathrm{cH}}$ & $3.16 \pm 0.038^{\mathrm{dH}}$ & $0.00 \pm 0.000^{\mathrm{eA}-\mathrm{N}}$ \\
\hline 9 & $4.64 \pm 0.038^{\mathrm{al}}$ & $4.26 \pm 0.052^{b l}$ & $3.94 \pm 0.029^{\mathrm{cl}}$ & $3.57 \pm 0.038^{\mathrm{dl}}$ & $0.00 \pm 0.000^{\mathrm{eA}-\mathrm{N}}$ \\
\hline 10 & $5.08 \pm 0.076^{\text {aJ }}$ & $4.71 \pm 0.063^{\mathrm{bJ}}$ & $4.35 \pm 0.050^{\mathrm{cJ}}$ & $3.99 \pm 0.014^{d J}$ & $0.00 \pm 0.000^{\mathrm{eA}-\mathrm{N}}$ \\
\hline 11 & $5.67 \pm 0.029^{\mathrm{aK}}$ & $4.96 \pm 0.053^{\mathrm{bK}}$ & $4.63 \pm 0.038^{\mathrm{cK}}$ & $4.38 \pm 0.029^{\mathrm{dK}}$ & $0.00 \pm 0.000^{\mathrm{eA}-\mathrm{N}}$ \\
\hline 12 & $6.01 \pm 0.052^{\mathrm{aL}}$ & $5.25 \pm 0.050^{\mathrm{bL}}$ & $4.92 \pm 0.029^{\mathrm{cL}}$ & $4.74 \pm 0.038^{\mathrm{dL}}$ & $0.00 \pm 0.000^{\mathrm{eA}-\mathrm{N}}$ \\
\hline 13 & $6.42 \pm 0.076^{\mathrm{aM}}$ & $5.40 \pm 0.050^{\mathrm{bM}}$ & $5.19 \pm 0.038^{\mathrm{cM}}$ & $4.99 \pm 0.038^{\mathrm{dM}}$ & $0.00 \pm 0.000^{\mathrm{eA}-\mathrm{N}}$ \\
\hline 14 & $6.75 \pm 0.050^{\mathrm{aN}}$ & $5.78 \pm 0.058^{\mathrm{bN}}$ & $5.50 \pm 0.050^{\mathrm{cN}}$ & $5.25 \pm 0.050^{\mathrm{dN}}$ & $0.00 \pm 0.000^{\mathrm{eA}-\mathrm{N}}$ \\
\hline
\end{tabular}

Values followed by the same small letter (a-e) within the same row are not the significantly different $(p>0.05)$ according to Duncan's multiple range test. Values followed by the same capital letter $(A-N)$ within the same column are not the significantly different $(p>0.05)$ according to Duncan's multiple range test.

concentration of $1.50 \%(\mathrm{v} / \mathrm{v})$ after the $14^{\text {th }}$ day of incubation (Table 6).

A visible growth of the investigated Fusarium species was not observed after 30 days of incubation at the concentration of $1.50 \%(\mathrm{v} / \mathrm{v})$. The transfer of inoculated spores free from extract did not result in spore germination; hence, this concentration is the minimum fungicide concentration (MFC) for the observed Fusarium species. The greatest reduction in the mycelial growth by increasing extract concentrations was observed in $F$. 
Table 4. Effect of the basil extract on the colony growth of $F$. proliferatum.

\begin{tabular}{|c|c|c|c|c|c|}
\hline \multirow{3}{*}{ Day } & \multirow{3}{*}{ Control } & \multicolumn{4}{|c|}{ Colony growth diameter (mean and $\mathrm{SD}=6)(\mathrm{cm})$} \\
\hline & & \multicolumn{4}{|c|}{ Basil extract concentration $(\%(v / v))$} \\
\hline & & 0.16 & 0.35 & 0.70 & 1.50 \\
\hline 1 & $0.52 \pm 0.029^{\mathrm{abA}}$ & $0.49 \pm 0.014^{\mathrm{abA}}$ & $0.00 \pm 0.000^{\mathrm{cdeA}}$ & $0.00 \pm 0.000^{\text {cdeABC }}$ & $0.00 \pm 0.000^{\text {cdeA-N }}$ \\
\hline 2 & $1.58 \pm 0.029^{\mathrm{abB}}$ & $1.53 \pm 0.058^{\mathrm{abB}}$ & $0.72 \pm 0.029^{c B}$ & $0.00 \pm 0.000^{\mathrm{de} A B C}$ & $0.00 \pm 0.000^{\mathrm{eA}-\mathrm{N}}$ \\
\hline 3 & $2.63 \pm 0.058^{\mathrm{aC}}$ & $2.32 \pm 0.029^{\mathrm{bC}}$ & $1.40 \pm 0.000^{\mathrm{cC}}$ & $0.00 \pm 0.000^{\mathrm{de} A B C}$ & $0.00 \pm 0.000^{\mathrm{eA}-\mathrm{N}}$ \\
\hline 4 & $3.25 \pm 0.050^{\mathrm{aD}}$ & $2.81 \pm 0.038^{b D}$ & $2.09 \pm 0.088^{\mathrm{CD}}$ & $0.85 \pm 0.050^{\mathrm{eD}}$ & $0.00 \pm 0.000^{\mathrm{eA}-\mathrm{N}}$ \\
\hline 5 & $3.83 \pm 0.025^{\mathrm{aE}}$ & $3.34 \pm 0.052^{\mathrm{bE}}$ & $2.58 \pm 0.029^{\mathrm{cE}}$ & $1.62 \pm 0.029^{\mathrm{eE}}$ & $0.00 \pm 0.000^{\mathrm{eA}-\mathrm{N}}$ \\
\hline 6 & $4.11 \pm 0.038^{\mathrm{aF}}$ & $3.71 \pm 0.038^{\mathrm{bF}}$ & $3.05 \pm 0.050^{\mathrm{CF}}$ & $2.11 \pm 0.038^{\mathrm{eF}}$ & $0.00 \pm 0.000^{\mathrm{eA}-\mathrm{N}}$ \\
\hline 7 & $4.48 \pm 0.066^{\mathrm{aG}}$ & $4.03 \pm 0.025^{\mathrm{bG}}$ & $3.72 \pm 0.029^{\mathrm{CG}}$ & $2.53 \pm 0.029^{\mathrm{eG}}$ & $0.00 \pm 0.000^{\mathrm{eA}-\mathrm{N}}$ \\
\hline 8 & $4.88 \pm 0.066^{\mathrm{aH}}$ & $4.40 \pm 0.050^{\mathrm{bH}}$ & $3.94 \pm 0.072^{\mathrm{CH}}$ & $2.98 \pm 0.029^{\mathrm{eH}}$ & $0.00 \pm 0.000^{\mathrm{eA}-\mathrm{N}}$ \\
\hline 9 & $5.34 \pm 0.014^{\mathrm{al}}$ & $4.80 \pm 0.000^{\mathrm{bl}}$ & $4.16 \pm 0.063^{c 1}$ & $3.33 \pm 0.058^{\mathrm{el}}$ & $0.00 \pm 0.000^{\mathrm{eA}-\mathrm{N}}$ \\
\hline 10 & $5.87 \pm 0.029^{\mathrm{aJ}}$ & $5.18 \pm 0.076^{\mathrm{bJ}}$ & $4.49 \pm 0.088^{c\lrcorner}$ & $3.64 \pm 0.038^{\mathrm{eJK}}$ & $0.00 \pm 0.000^{\mathrm{eA}-\mathrm{N}}$ \\
\hline 11 & $6.25 \pm 0.050^{\mathrm{aK}}$ & $5.43 \pm 0.029^{\mathrm{bK}}$ & $4.64 \pm 0.038^{\mathrm{cKL}}$ & $4.01 \pm 0.014^{\mathrm{eJK}}$ & $0.00 \pm 0.000^{\mathrm{eA}-\mathrm{N}}$ \\
\hline 12 & $6.65 \pm 0.050^{\mathrm{aL}}$ & $5.63 \pm 0.066^{\mathrm{bL}}$ & $4.72 \pm 0.029^{\mathrm{cKL}}$ & $4.05 \pm 0.025^{\mathrm{eL}}$ & $0.00 \pm 0.000^{\mathrm{eA}-\mathrm{N}}$ \\
\hline 13 & $7.09 \pm 0.038^{\mathrm{aM}}$ & $5.92 \pm 0.076^{\mathrm{bM}}$ & $4.82 \pm 0.029^{\mathrm{cM}}$ & $4.11 \pm 0.014^{\mathrm{eMN}}$ & $0.00 \pm 0.000^{\mathrm{eA}-\mathrm{N}}$ \\
\hline 14 & $7.39 \pm 0.038^{\mathrm{aN}}$ & $6.27 \pm 0.058^{\mathrm{bN}}$ & $4.93 \pm 0.025^{\mathrm{cN}}$ & $4.12 \pm 0.029^{\mathrm{eMN}}$ & $0.00 \pm 0.000^{\mathrm{eA}-\mathrm{N}}$ \\
\hline
\end{tabular}

Values followed by the same small letter (a-e) within the same row are not the significantly different $(p>0.05)$ according to Duncan's multiple range test. Values followed by the same capital letter (A-N) within the same column are not the significantly different $(p>0.05)$ according to Duncan's multiple range test.

Table 5. Effect of the basil extract on the colony growth of $F$. subglutinans.

\begin{tabular}{|c|c|c|c|c|c|}
\hline \multirow{3}{*}{ Day } & \multirow{3}{*}{ Control } & \multicolumn{4}{|c|}{ Colony growth diameter (mean and $\mathrm{SD}=6)(\mathrm{cm})$} \\
\hline & & \multicolumn{4}{|c|}{ Basil extract concentrations (\% (v/v)) } \\
\hline & & 0.16 & 0.35 & 0.70 & 1.50 \\
\hline 1 & $0.46 \pm 0.014^{\mathrm{abA}}$ & $0.43 \pm 0.029^{\mathrm{abA}}$ & $0.22 \pm 0.029^{\mathrm{cA}}$ & $0.00 \pm 0.000^{\mathrm{de} A \mathrm{~B}}$ & $0.00 \pm 0.000^{\text {deA-N }}$ \\
\hline 2 & $1.94 \pm 0.063^{\mathrm{abB}}$ & $1.87 \pm 0.058^{\mathrm{abB}}$ & $0.52 \pm 0.029^{\mathrm{cB}}$ & $0.00 \pm 0.000^{\mathrm{de} A B}$ & $0.00 \pm 0.000^{\mathrm{eA}-\mathrm{N}}$ \\
\hline 3 & $2.65 \pm 0.043^{\mathrm{abc}}$ & $2.59 \pm 0.014^{a b c}$ & $0.79 \pm 0.038^{\mathrm{cC}}$ & $0.16 \pm 0.014^{\mathrm{dC}}$ & $0.00 \pm 0.000^{\mathrm{eA}-\mathrm{N}}$ \\
\hline 4 & $3.13 \pm 0.066^{\mathrm{abD}}$ & $3.08 \pm 0.066^{\mathrm{abD}}$ & $1.50 \pm 0.050^{\mathrm{cD}}$ & $1.18 \pm 0.025^{\mathrm{dD}}$ & $0.00 \pm 0.000^{\mathrm{eA}-\mathrm{N}}$ \\
\hline 5 & $3.47 \pm 0.058^{\mathrm{abE}}$ & $3.43 \pm 0.029 \mathrm{abE}$ & $2.23 \pm 0.058^{\mathrm{cE}}$ & $1.53 \pm 0.029^{\mathrm{dE}}$ & $0.00 \pm 0.000^{\mathrm{eA}-\mathrm{N}}$ \\
\hline 6 & $3.81 \pm 0.038^{\mathrm{abF}}$ & $3.74 \pm 0.038^{\mathrm{abF}}$ & $2.64 \pm 0.052^{\mathrm{cF}}$ & $1.77 \pm 0.076^{\mathrm{dF}}$ & $0.00 \pm 0.000^{\mathrm{eA}-\mathrm{N}}$ \\
\hline 7 & $4.40 \pm 0.100^{\mathrm{aG}}$ & $4.19 \pm 0.063^{\mathrm{bG}}$ & $2.98 \pm 0.029^{c G}$ & $2.71 \pm 0.063^{\mathrm{dG}}$ & $0.00 \pm 0.000^{\mathrm{eA}-\mathrm{N}}$ \\
\hline 8 & $4.81 \pm 0.100^{\mathrm{aH}}$ & $4.58 \pm 0.058^{\mathrm{bH}}$ & $3.35 \pm 0.050^{\mathrm{cH}}$ & $3.19 \pm 0.290^{\mathrm{dH}}$ & $0.00 \pm 0.000^{\mathrm{eA}-\mathrm{N}}$ \\
\hline 9 & $5.15 \pm 0.071^{\mathrm{al}}$ & $4.73 \pm 0.208^{\mathrm{bl}}$ & $3.56 \pm 0.038^{\mathrm{cl}}$ & $3.35 \pm 0.050^{\mathrm{dl}}$ & $0.00 \pm 0.000^{\mathrm{eA}-\mathrm{N}}$ \\
\hline 10 & $5.92 \pm 0.104^{\mathrm{aJ}}$ & $5.22 \pm 0.076^{\mathrm{bJ}}$ & $3.88 \pm 0.029^{\mathrm{cJ}}$ & $3.67 \pm 0.058^{d J}$ & $0.00 \pm 0.000^{\mathrm{eA}-\mathrm{N}}$ \\
\hline 11 & $6.11 \pm 0.095^{\mathrm{aK}}$ & $5.63 \pm 0.075^{\mathrm{bK}}$ & $4.32 \pm 0.029^{\mathrm{cK}}$ & $4.10 \pm 0.000^{\mathrm{dK}}$ & $0.00 \pm 0.000^{\mathrm{eA}-\mathrm{N}}$ \\
\hline 12 & $6.32 \pm 0.029^{\mathrm{aL}}$ & $5.97 \pm 0.104^{\mathrm{bL}}$ & $4.58 \pm 0.029^{c L}$ & $4.42 \pm 0.029^{\mathrm{dL}}$ & $0.00 \pm 0.000^{\mathrm{eA}-\mathrm{N}}$ \\
\hline 13 & $6.63 \pm 0.025^{\mathrm{aM}}$ & $6.24 \pm 0.052^{\mathrm{bM}}$ & $5.00 \pm 0.050^{\mathrm{cM}}$ & $4.74 \pm 0.052^{\mathrm{dM}}$ & $0.00 \pm 0.000^{\mathrm{eA}-\mathrm{N}}$ \\
\hline 14 & $7.00 \pm 0.100^{\mathrm{aN}}$ & $6.43 \pm 0.058^{\mathrm{bN}}$ & $5.27 \pm 0.076^{\mathrm{cN}}$ & $4.95 \pm 0.050^{\mathrm{dN}}$ & $0.00 \pm 0.000^{\mathrm{eA}-\mathrm{N}}$ \\
\hline
\end{tabular}

Values followed by the same small letter (a-e) within the same row are not the significantly different $(p>0.05)$ according to Duncan's multiple range test. Values followed by the same capital letter $(A-N)$ within the same column are not the significantly different $(p>0.05)$ according to Duncan's multiple range test.

proliferatum and $F$. subglutinans, which implies that their sensitivity is higher than sensitivity of other two species (Tables 2 to 5).

In general, data on the antifungal activity of basil essential oils and extracts against Fusarium species and other species such as Aspergillus species are rather scarce (Hitokoto et al., 1980; Baratta et al., 1998; Zollo et al., 1998; Basilico and Basilico, 1999; Özkan and Erkmen, 2001; Alpsoy, 2010). On the other hand, data on the effects of the essential oils and extracts obtained from 
Table 6. Inhibitory effect (\%) of basil extract on colony growth of Fusarium species after 14 days of incubation.

\begin{tabular}{lcccc}
\hline & \multicolumn{4}{c}{ Basil extract concentration $(\%(\mathbf{v} / \mathbf{v}))$} \\
\cline { 2 - 5 } Fungi & $\mathbf{0 . 1 6}$ & $\mathbf{0 . 3 5}$ & $\mathbf{0 . 7 0}$ & $\mathbf{1 . 5 0}$ \\
\cline { 2 - 5 } & \multicolumn{4}{c}{ Colony growth inhibition (\%) } \\
\hline F. verticillioides & $8.89 \pm 1.217^{\mathrm{aA}}$ & $13.13 \pm 1.516^{\mathrm{aBC}}$ & $16.73 \pm 0.882^{\mathrm{aBC}}$ & $100.0 \pm 0.000^{\mathrm{abcdD}}$ \\
F. oxysporum & $14.32 \pm 0.440^{\mathrm{bA}}$ & $18.51 \pm 1.162^{\mathrm{bB}}$ & $22.21 \pm 1.317^{\mathrm{bC}}$ & $100.0 \pm 0.000^{\mathrm{abcdD}}$ \\
F. subglutinans & $8.08 \pm 2.076^{\mathrm{CA}}$ & $24.74 \pm 2.160^{\mathrm{cB}}$ & $29.27 \pm 1.510^{\mathrm{cC}}$ & $100.0 \pm 0.000^{\mathrm{abcdD}}$ \\
F. proliferatum & $15.22 \pm 0.395^{\mathrm{dA}}$ & $33.37 \pm 0.623^{\mathrm{dB}}$ & $44.30 \pm 0.255^{\mathrm{dC}}$ & $100.0 \pm 0.000^{\mathrm{abcdD}}$ \\
\hline
\end{tabular}

Values followed by the same small letter (a-e) within the same row are not the significantly different $(p>0.05)$ according to Duncan's multiple range test. Values followed by the same capital letter $(A-N)$ within the same column are not the significantly different $(p>0.05)$ according to Duncan's multiple range test.

other spice herbs against Fusarium species are more profuse than those of basil essential oils and basil extracts (Velluti et al., 2003). Furthermore, the antimicrobial activity of an essential oil is attributed mainly to its major compounds. The synergistic or antagonistic effect of one compound in minor percentage in the mixture has to be considered (Daferera et al., 2003; Velluti et al., 2003). This clearly suggests that the antifungal activity of essential oil or extract of each herb or even a genotype (Hasegawa et al., 1997) has to be investigated separately against a particular fungal species.

Lis-Balchin et al. (1998) studied the antifungal activity of the methyl chavicol type of basil essential oil against $F$. culmorum (W.G. Smith) Sacc. and found that the oil exhibited $71 \%$ reduction in the mycelial growth of the tested species.

Reuveni et al. (1984) studied the percentage of inhibition of principle constituents of basil against $F$. oxysporum. They found that eugenol demonstrated the highest percentage of inhibition (100\%) against $F$. oxysporum, whereas for linalol and methyl chavicol, showed an inhibition of 26.4 and $30.3 \%$, respectively. However, the results reported by Adigüzel et al. (2005) showed that none of the three tested basil extracts (ethanol, methanol, and hexane) exhibited antifungal activities against $F$. oxysporum.

Basil oil was found to significantly affect the growth of $F$. verticillioides after 7 days of incubation (Fandohan et al., 2004). It totally inhibited the growth of $F$. verticillioides at concentrations lower than $2.7 \mu \mathrm{L} / \mathrm{mL}$. Basil oil remained effective over 21 days, with minimal inhibitory concentrations of $1.3 \mu \mathrm{L} / \mathrm{mL}$. Soliman and Badeaa (2002) found that basil oil demonstrated fungistatic activity against $F$. verticillioides at concentration of 2000 and fungicidal activity at concentration of $3000 \mathrm{ppm}$. Essential oil from $O$. gratissimum $\mathrm{L}$. originating from Kenya showed a strong inhibitory effect against fumonisin $\mathrm{B}_{1}\left(\mathrm{FB}_{1}\right)$ production by $F$. verticillioides (Dambolena et al., 2009), which can be attributed to its high eugenol content. Jayashree and Subramanvam (1999) reported that the antiaflatoxigenic activity of eugenol was due to the inhibition of lipid peroxidation.

Little is known about the effect of basil essential oils on the growth of $F$. subglutinans and $F$. proliferatum. Garcia et al. (2008) found that citral (monoterpene constituent of essential oils) at concentrations of $0.6 \%$ or above, completely suppressed the mycelial growth of phytopathogenic F. subglutinans f. sp. ananas (syn. F. guttiforme Nirenberg \& O'Donnell). Comparing with citral, $1 \%$ of citronellal (monoterpenes) and L-carvone (aldehyde functional group) showed an inhibition of approximately $80 \%$ of $F$. subglutinans f. sp. ananas mycelium growth. $F$. subglutinans $\mathrm{f}$. $\mathrm{sp}$. ananas germination was completely inhibited by $0.4 \%$ citral, $0.6 \%$ citronellal, and $0.8 \% \mathrm{~L}$ carvone.

The investigated basil extract, in addition to the growth inhibitory effect, caused changes in the macro and micro morphology of fungi. At higher concentrations ( 0.35 and $0.70 \%(\mathrm{v} / \mathrm{v}))$ reduced growth of aerial mycelium in all investigated Fusarium species was observed, accompanied with stronger medium pigmentation in the case of $F$. proliferatum, and $F$. verticillioides. At these concentrations, the microscopic examination confirmed the presence of hyphae deformations with a frequent occurrence of fragmentations, thickenings and diminished sporulation. In $F$. proliferatum, $0.70 \% \quad(\mathrm{v} / \mathrm{v})$ extract concentration caused granular appearance of hyphae and deviations as well as deformed phyalides. These deformations may be related to the changes at the cellular level (decrease in the oxygen uptake, reduction of the cellular growth, inhibition of the synthesis of lipids, proteins and nucleic acids, changes in the lipid profile of the cell membrane, and inhibition of the fungal cell wall synthesis (Adetumbi et al., 1986; Ghannoum, 1988; Gupta and Porter, 2001; Corzo-Martinez et al., 2007). For example, the investigations of cellular ultra structures of A. niger after exposure to etheric oils of thyme and ajoene extracted from garlic caused the absence of surface ornaments, thinning of cell walls, abruption of the cell membrane from the cell wall, surface hyphae deviations, and the destruction of cellular organelles (Yoshida et al.,1987; Rasooli et al., 2006). It can be assumed that active components of essential oils like thymol, eugenol, and carvacrol damage the biological membrane by bonding to essential enzymes integrated with the cellular membranes (Knobloch et al., 1989; Davidson, 2001). 
Literature data suggest that essential oils can be practically applied in post-harvest disease control or mycotoxins inhibition on stored kernels (Soliman and Badeaa, 2002). Basil essential oil significantly diminishes the severity of grain infestation with $F$. verticillioides and inhibits the radial colony growth in comparison to the control (Kabore et al., 2006). Essential oil of $O$. gratissimum was found to be highly efficient against $F$. verticillioides producing high infection suppression figure of $95-100 \%$ (Nguefack et al., 2008). These findings showed that essential oils reduced the natural microbial load of kernels by 95 to $100 \%$. The use of this oil at 200 ppm concentration significantly reduced $(86 \%)$ the mycelial growth of $F$. verticillioides as well as spore germination at $500 \mathrm{ppm}$. The in vivo test showed that oil from $O$. basilicum reduced significantly the incidence of $F$. verticillioides in artificially inoculated corn, compared to the controls (Fandohan et al., 2004). A reduction of the toxin level up to $60 \%$, however, was observed at concentrations of $>4.8 \mu \mathrm{L} / \mathrm{g}$ and complete inhibition occurred at $6.4 \mu \mathrm{L} / \mathrm{g}$. At the concentration of $4.8 \mu \mathrm{L} / \mathrm{g}$, basil oil significantly adversely affected the germination of corn kernels. These findings suggest that at $4.8 \mu \mathrm{L} / \mathrm{g}$ concentration, basil oil can be recommended only for the treatment of kernels intended for human and animal consumption, but not for the treatment of kernels to be used as a seed material.

\section{Conclusions}

The obtained results suggest that the investigated basil extract, besides improving a sensory appearance of food, could be used as preserving agent against Fusarium species ( $F$. oxysporum, $F$. proliferatum, $F$. subglutinans, and $F$. verticillioides) which are known as frequent contaminants of food commodities. Further investigations should deal with broadening the practical application of the basil extract especially with regards to its role in protection of cereals and cereal products against Fusarium species and their metabolites.

\section{ACKNOWLEDGMENT}

The study is the part of the investigations realised with the scope of the Project No. TR-31017 financially supported by the Ministry of Science and Technological Development of the Republic of Serbia.

\section{REFERENCES}

Adetumbi MA, Javor GT, Lau BHS (1986). Allium sativum (garlic) inhibits lipid synthesis by Candida albicans. Antimicrob. Agents. Chemother., 30: 499-501.

Adigüzel $A$, Güllüce $M$, Şengül $M$, Öğütcü $H$, Şahǐn $F$, Karaman I (2005). Antimicrobial effects of Ocimum basilicum (Labiatae) exract. Turk. J. Biol., 29: 155-160.
Alpsoy $L$ (2010). Inhibitory effect of essential oil on aflatoxin activities. Afr. J. Biotechnol., 9(17): 2474-2481.

Bakkali F, Averbeck S, Averbeck D, Idaomar M (2008). Biological effects of essential oils - A review. Food Chem. Toxicol., 46: 446475.

Baratta MT, Dorman HJD, Deas SG, Figueiredo AC, Baroso JG, Ruberto $G$ (1998). Antimicrobial and antioxidant properties of some commercial essential oils. Flavour Fragrance J., 13: 235-244.

Basilico MZ, Basilico JC (1999). Inhibitory effects of some spice essential oils on Aspergillus ochraceus NRRL 3174 growth and ochratoxin A production. Lett. Appl. Microbiol., 23: 238-241.

Benkeblia N (2004). Antimicrobial activity of essential oil extracts of various onions (Allium cepa) and garlic (Allium sativum). LWT, 37: 263-268.

Burt S (2004). Essential oils: their antibacterial properties and potential applications in foods-a review. Int. J. Food Microbiol., 94: 223-253.

Ceylan E, Fung CYD (2004). Antimicrobial activity of spices. J. Rapid Meth. Autom. Microbiol., 12: 1-55.

Corzo-Martinez M, Corzo N, Villamiel M (2007). Biological properties of onions and garlic. Trends. Food Sci. Tech., 18: 609-625.

Daferera DJ, Ziogas BN, Polissiou MG (2003). The effectiveness of plant essential oils in the growth of Botrytis cinerea, Fusarium sp. and Clavibacter michiganensis subsp. michiganensis. Crop Prot., 22: 3944.

Dambolena SJ, Zunino PM, López GA, Rubinstein RH, Zygadlo AJ, Mwangi WJ, Thoithi NG, Kibwage OI, Mwalukumbi MJ, Kariuki TS (2010). Essential oils composition of Ocimum basilicum L. and Ocimum gratissimum L. from Kenya and their inhibitory effect on growth and fumonisin production by Fusarium verticillioides. Innovat. Food Sci. Emerg. Tech., 11(2): 239-422.

Davidson PM (2001). Chemical preservatives and naturally antimicrobial compounds, in Doyle MP, Beuchat LR, Montiville TJ (Eds.), Food Microbiology - Fundamentals Frontiers, ASM Press, Washington, pp. 593-628.

Dorman HJD, Deans G (2000). Antimicrobial agents from plants: antibacterial activity of plant volatile oils. J. Appl. Microbiol., 88: 308316.

Fandohan P, Gbenou JD, Gnonlonfin B, Hell K, Marasas WFO, Wingfield MJ (2004). Effect of essential oils in the growth of Fusarium verticillioides and fuminisins contamination in corn. J. Agric. Food Chem., 52: 6824-6829.

Fawzi EM, Khalil AA, Afifi AF (2009). Antifungal effect of some plant extracts on Alternaria alternata and Fusarium oxysporum. Afr. J. Biotechnol., 8(11): 2590-2597.

Fung W, Zheng X (2007). Essential oils to control Alternaria alternata in vitro and in vivo. Food Contr., 18: 1126-1130.

Garcia R, Alves ES., Santos MP, Viégas Aquije GMF, Fernandes AAR, Santos RB, Ventura JA, Fernandes PMB, (2008). Antimicrobial activity and potential use of monoterpenes as tropical fruits preservatives. Braz. J. Microbiol., 39: 163-168.

Ghannoum MA (1988). Studies on the anticandicidal mode of action of Allium sativum (garlic). J. Gen. Microbiol., 134: 2917-2924.

Gupta N, Porter TD (2001). Garlic and garlic-derived compounds inhibit human squalene monooxygenase. J. Nutr., 131: 1662-1667.

Hasegawa $Y$, Tajima K, Toi N, Sugimura Y (1997). Characteristic components found in the essential oil of Ocimum basilicum L. Flavour Fragrance J., 12: 195-200.

Hitokoto H, Morozumi S, Wauke T, Sakai S, Kurata H (1980). Inhibitory effects of spices on growth and toxin production of toxigenic fungi. Appl. Environ. Microbiol., 39: 818-822.

Hussain IA, Anwar F, Hussain-Sherazi TS, Przybylski R (2008). Chemical composition, antioxidant and antimicrobial activities of basil (Ocimum basilicum) essential oils depends on seasonal variations. Food Chem., 108: 986-995.

Joffe AZ (1974). Toxicity of Fusarium poae and F. sporotrichioides and its relation to alimentary toxic aleukia, in Purchase IFH (Ed.), Mycotoxins, Elsevier, Amsterdam-Oxford-New York, pp. 229-261.

Jayashree T, Subramanvam C (1999). Antiaflatoxigenic activity of eugenol is due to inhibition of lipid peroxidation. Lett. Appl. Microbiol., 28: 179-183.

Kabore KB, Koïta E, Ouedraogo I, Nebie R (2006). Efficiency of some local plants essential oil against seed-borne and seed transmitted 
fungi of rice. Africa Rice Congress, 31 July - 4 August, 2006, Dar as Salaam, Tauzanie.

Karan D, Vukojević J, Milićević D, Ljajević-Grbić M, Janković V (2005). Presence of moulds and mycotoxins in spices. Proc. Nat. Sci. Matica Srpska, 108: 77-85.

Kocić-Tanackov DS, Dimić RG, Tepić N, Vujičić LB (2009). Influence of Allium ampeloprasum L. and Allium cepa L. essential oils to growth of some yeasts and moulds. Proc. Nat. Sci. Matica Srpska, 116: 121130.

Knobloch K, Pauli A, Iberl B, Weigand H, Weis N (1989). Antibacterial and antifungal properties of essential oil components. J. Essent. Oil Res., 1: 119-128.

Kurita N, Miyaji M, Kurane R, Takahara Y (1981). Antifungal activity of components of essential oils. Agric. Biol. Chem., 45: 945-952.

Lević J, Stanković S, Bočarov-Stančić A, Škrinjar M, Mašić Z (2004). The Overview on Toxigenic Fungi and Mycotoxins in Serbia and Montenegro, in Logrieco A, Visconti A (Eds.), An Overview on toxigenic fungi and mycotoxins in Europe, Kluwer Academic Publishers, Dordrecht-Boston-London, pp. 201-218.

Lis-Balchin M, Deans SG, Eaglesham E (1998). Relationship between bioactivity and chemical composition of commercial essential oils. Flavour Fragrance J., 13: 98-104.

Marasas WFO, Nelson PE, Toussoun TA (1984). Toxigenic Fusarium species. Identity and Mycotoxicology, The Pennsylvania State University Press, University Park and London, Pennsylvania, pp. 1328.

McKee HL (1995). Microbial contamination of spices and herbs: A review. LWT, 28: 1-11.

Meena MR, Sethi V (1994). Antimicrobial activity of essential oils from spices. J. Food Sci. Tech., 31: 68-70.

Nguefack J, Leth V, Lakagne-Dongmo JB, Torp J, Amvam Zollo PH, Nyasse $S$ (2008). Use of three essential oils as seed treatments against seed-borne fungi of rice (Oryza sativa L.). Amer.-Eurasian J. Agric. Environ. Sci., 4: 554-560.

Özkan M, Erkmen O (2001). Antimicrobial activity of the essential oils of Turkish plant spices. Eur. Food Res. Technol., 212: 658-660.

Pandey DK, Tripathi NN, Tripathi RD, Dixit SN (1982). Fungitoxic and phytotoxic properties of the essential oil of Caesulia axillaris Roxb. (Compositae). Angewandte Botanik, 56: 256-257.

Pitt IJ, Hocking DA (1997). Fungi and food spoilage, Second Edition, Blackie Academic and Professional, University Press, Cambridge, pp. 411-415.

Rasooli I, Rezaei MB, Allameh A (2006). Growth inhibition and morphological alterations of Aspergillus niger by essential oils from Thymus eriocalyx and Thymus x-porlock. Food Control, 17: 359-364.

Reuveni R, Fleisher A, Putievsky E (1984). Fungistatic activity of essential oils from Ocimum basilicum chemotypes. J. Phytopathol., 110: 20-22.
Sartoratotto A, Machado ALM, Delarmelina C, Figueira GM, Duarte MCT, Rehder VLG (2004). Composition and antimicrobial activity of essential oils from aromatic plants used in Brazil. Braz. J. Microbiol., 35: 275-280.

Sokovic M, van Griensven LJD (2006). Antimicrobial activity of essential oils and their components against in the three major pathogens of the cultivated button mushroom, Agaricus bisporus. Eur. J. Plant Pathol., 116: 211-224.

Soliman KM, Badeaa RI (2002). Effect of oil extracted from some medicinal plants on different mycotoxigenic fungi. Food Chem. Toxicol., 40: 1669-1675.

Suppakul P, Miltz J, Sonneveld K, Bigger WS (2003). Antimicrobial properties of basil and its possible application in food packaging. $\mathrm{J}$. Agr. Food Chem., 51: 3197-3207.

Tajkarimi MM, Ibrahim SA, Cliver DO (2010). Antimicrobial herb and spice compounds in food. Food Contr., 21 (9): 1199-1218.

Tepe B, Daferera D, Sokomen A, Sokomen M, Polissiou M (2005). Antimicrobial and antioxidant activites of the essential oils and various extracts of Salvia tomentosa Miller (Lamiaceae). Food Chem., 90: 333-340.

Thrane $U$ (2001). Developments in the taxonomy of Fusarium species based on secondary metabolites, in Summerell BA, Leslie JF, Backhouse D, Bryden WL, Burgess LW (Eds.), Fusarium - Paul E. Nelson Memorial Symposium, APS Press, St. Paul, Minnesota, pp. 29-49.

Velluti A, Sanchis V, Ramos AJ, Egido J, Marín S (2003). Inhibitory effect of cinnamon, lemongrass, oregano and palmarose essential oils on growth and fumonisin $\mathrm{B}_{1}$ production by Fusarium proliferatum in maize grain. Int. J. Food Microbiol., 89: 145-154.

Viuda-Martos M, Ruiz-Navajas Y, Fernández-López J, Pérez-Álvarez J (2007). Antifungal activities of thyme, clove and origano essential oils. J. Food Saf., 27: 91-101.

Viuda-Martos M, Ruiz-Navajas Y, Fernández-López J, Pérez-Álvarez J (2008). Antifungal activity of lemon (Citrus lemon L.), mandarin (Citrus reticulata L.), grapefruit (Citrus paradisi L.) and orange (Citrus sinensis L.) essential oils. Food Contrl., 19: 1130-8.

Yoshida S, Kaduga S, Hayashi N, Ushiroguchi T, Matsuura H, Nakagwa $S$ (1987). Antifungal activity of ajoene derived from garlic. Appl. Environ. Microbiol., 53: 615-617.

Zollo PHA, Biyiti L, Tchoumbougnang F, Menut C, Lamaty G, Bouchet P (1998). Aromatic plants of tropical Central Africa. Part XXXII. Chemical composition and antifungal activity of thirteen essential oils from aromatic plants of Cameroon. Flavour Fragrance J., 13: 107114. 